\title{
Penerapan Cara Budidaya Ikan yang Baik pada Pembesaran Udang Vaname (Litopenaeus vanname) di Pesisir Daerah Istimewa Yogyakarta
}

\author{
Application of Good Fish Farming Practice for Vaname Shrimp \\ (Litopenaeus vanname) in the Coast of Yogyakarta
}

\author{
Lucky R. Nugroho*, Sukardi \& Bambang Triyatmo \\ Departemen Perikanan, Fakultas Pertanian UGM \\ J. Flora, Gedung A4, Bulaksumur, Yogyakarta 55281 \\ *Penulis untuk korespondensi, e-mail: luckyrestyannugroho@gmail.com
}

\begin{abstract}
Abstrak
Penelitian ini bertujuan untuk mengetahui penerapan metode budidaya ikan yang baik serta faktor-faktor yang mempengaruhi aktivitas pembesaran udang vaname (Litopenaeus vannamei) di pesisir Daerah Istimewa Yogyakarta. Selain itu, penelitian ini juga bertujuan untuk mengetahui teknologi budidaya udang yang diterapkan petani di wilayah pesisir Daerah Istimewa Yogyakarta. Metode dasar yang digunakan dalam penelitian ini adalah penelitian deskriptif dengan instrumen penelitian berupa kuesioner. Penelitian deskriptif bertujuan untuk memberikan gambaran tentang suatu masyarakat, kelompok orang tertentu atau gambaran suatu gejala. Teknik pengumpulan data dilakukan dengan wawancara dan observasi terstruktur untuk mendapatkan gambaran lebih rinci tentang suatu fenomena. Lokasi penelitian ditentukan secara purposive sampling, fokus pada Sidorejo, Banaran, Galur, Kulon Progo, Kuwaru dan Ngentak, Poncosari, Srandakan, Bantul. Alasan untuk mengambil 3 area ini karena sebagai pusat produksi udang vaname pertama dan paling lama beroperasi di wilayah pesisir Daerah Istimewa Yogyakarta. Responden ditentukan secara proporsional random sampling dari 3 area yang ditentukan. Penelitian ini berlangsung mulai 18 Juni 2015 - 12 Juli 2015. Hasilnya menunjukkan penerapan metode budidaya ikan yang baik pada aktivitas pembesaran udang vaname ( $L$. vannamei) di pesisir Daerah Istimewa Yogyakarta meliputi 10 parameter. Sepuluh parameter ini meliputi: pemilihan lokasi; penentuan layout dan desain konstruksi; pemilihan wadah budidaya; biosekuritas; pemilihan benih ikan (udang); penggunaan pakan ikan (udang); penggunaan probiotik; penggunaan desinfektan; cara panen; peralatan pemanen. Penerapan usahatani ikan yang baik pada pembesaran udang vaname ( $L$. vannamei) di pesisir Daerah Istimewa Yogyakarta rata-rata $62,24 \%$. Faktor-faktor yang mempengaruhi penerapan usaha tani ikan yang baik dalam kegiatan pembesaran udang adalah adanya (komunikasi dan sosialisasi) tentang pembesaran udang secara teknis oleh karyawan perusahaan pakan dan probiotik. Konseling (komunikasi dan sosialisasi), verifikasi (recording), dan kontrol dalam bentuk sertifikasi belum dilakukan oleh Dinas Kelautan dan Perikanan. Teknologi budidaya udang vaname (L. vannamei) yang diterapkan oleh petani di pesisir Daerah Istimewa Yogyakarta adalah teknologi semi intensif.
\end{abstract}

Kata kunci: Cara budidaya ikan yang baik, semi intensif, teknologi budidaya udang, udang vaname

\begin{abstract}
This study aims to apply a good fish farming methods and determine factors that influence development the vaname shrimp (Litopenaeus vannamei) in the coast of Yogyakarta Special Region. This research also aims to find out an applicable technology of shrimp aquaculture for fish farmers in the coastal area of Special Region of Yogyakarta. The basic method used in this research is descriptive research with research instrument in the form of a questionnaire. The descriptive research aims to provide a picture of a society, a particular group of people or a picture of a symptom. Data collection techniques are conducted by interviews and structured observation to obtain a more detailed picture of a phenomenon. The location of the research is determined by purposive sampling, focusing on Sidorejo, Banaran, Galur, Kulon Progo, Kuwaru and Ngentak, Poncosari, Srandakan, Bantul. The reason for taking 3 areas is because as the center of production of shrimp vaname first and the longest operates in the coastal area ofSpecial Region of Yogyakarta. Respondents were determined by proportionate random sampling from 3 specified areas. This research took place from June 18,2015 , to July 12, 2015. The results showed the application of the good fish farming method on the activity of enlargement of shrimp vaname (L. vannamei) on the coast of Special Region of Yogyakarta covers 10 parameters. These ten parameters include site selection; determination of construction layout and design; selection of cultivation
\end{abstract}


containers; biosecurity; selection of fish seed (shrimp); use of fish feed (shrimp); use of probiotics; use of disinfectants; harvesting method and harvesting equipment. Application of good fish farming method at vaname shrimp (L. vannamei) aquaculture development in the coast of Yogyakarta Special Region averaged at $62.24 \%$. Factors that influence the application of good fish farming in the shrimp aquaculture development activities are the existence of communication and socialization services on the technical methods for the shrimp aquaculture by employees of feed and probiotics companies. Counseling (communication and socialization), verification (recording) and control in the form of certification has not been done by the Department of Marine and Fisheries of Indonesia. The technology of vaname shrimp farming (L. vannamei) applied by farmers in the coast of Yogyakarta Special Region is semi-intensive technology.

\section{Keywords: Good fish farming practice, semi-intensive, shrimp farming technology, vaname shrimp}

\section{Pengantar}

Udang vaname merupakan udang introduksi yang secara resmi ditetapkan sebagai salah satu komoditas unggulan perikanan budidaya oleh Menteri DKP pada tahun 2001 dan sejak itu perkembangan budidayanya sangat cepat. Selain Indonesia, negara-negara tetangga yang telah mengembangkan vaname antara lain China, Taiwan, dan Thailand. Vaname mempunyai ciri-ciri mampu hidup pada salinitas 4 - 45 ppt dengan salinitas optimal 10 - $30 \mathrm{ppt}$; kisaran suhu $24-32^{\circ} \mathrm{C}$ dengan suhu optimal 28 - $30{ }^{\circ} \mathrm{C}$; mampu bertahan pada kandungan oksigen terlarut $0,8 \mathrm{ppm}$ selama 3 - 4 hari tetapi disarankan kandungan oksigen terlarut minimal 4 ppm. $\mathrm{pH}$ air 7 - 8,5; kebutuhan protein rendah yaitu $32 \%$ dengan konversi pakan maksimal 1,5; dan prosentase daging 66 - 68\%, lebih tinggi jika dibandingkan udang windu yang hanya $62 \%$ (Direktorat Jenderal Perikanan Budidaya, 2013).

Teknologi budidaya udang vaname terdiri atas 2 tingkat, berupa: semi intensif (Badan Standardisasi Nasional, 2014 ${ }^{\mathrm{a}}$ ) dan intensif (Badan Standardisasi Nasional, $2014^{\mathrm{b}}$ ). Semi intensif adalah tingkat teknologi budidaya udang dengan padat penebaran benih sedang yang memanfaatkan pakan alami, pakan tambahan, dan input produksi lainnya. Indikator penerapan teknologi tingkat semi intensif diantaranya berupa kedalaman petak pembesaran udang minimal 0,8 m, luas petak pembesaran berkisar 1000 - 5000 $\mathrm{m}^{2}$, bentuk petak pembesaran persegi atau persegi panjang dan padat penebaran benih berkisar antara 50 - 79 ekor $/ \mathrm{m}^{2}$. Cerminan penerapan teknologi tingkat semi intensif adalah produksi total berkisar antara 0,4 - 0,8 kg/m², konversi pakan maksimal sebesar 1,5 serta kelangsungan hidup minimal $80 \%$ (Badan Standardisasi Nasional, $2014^{a}$ ). Intensif adalah tingkat teknologi budidaya udang dengan padat penebaran benih lebih tinggi dari pada tingkat semi intensif, serta memanfaatkan pakan alami, pakan tambahan, dan input produksi lainnya. Indikator penerapan teknologi tingkat intensif diantaranya berupa kedalaman petak pembesaran udang minimal $1,40 \mathrm{~m}$, luas petak pembesaran berkisar $1000-5000 \mathrm{~m}^{2}$, bentuk petak pembesaran persegi atau persegi panjang dan padat penebaran benih berkisar antara 80 - 120 ekor/m². Cerminan penerapan teknologi tingkat semi intensif adalah produksi total minimal $0,9 \mathrm{~kg} / \mathrm{m}^{2}$, konversi pakan maksimal sebesar 1,5 serta kelangsungan hidup minimal 80\% (Badan Standardisasi Nasional, $2014^{\text {b }}$ ).

Cara budidaya ikan yang baik (CBIB) adalah cara memelihara dan atau membesarkan ikan serta memanen hasilnya dalam lingkungan yang terkontrol sehingga memberikan jaminan keamanan pangan dari pembudidayaan dengan memperhatikan sanitasi, pakan, obat ikan, dan bahan kimia, serta bahan biologis (Kep. Men KKP, 2007). Maksud ditetapkannya keputusan tersebut yaitu untuk mengatur kegiatan pembudidayaan ikan bagi pembudidaya agar menerapkan cara budidaya ikan yang baik. Tujuan ditetapkannya keputusan ini yaitu untuk menjamin keamanan pangan hasil pembudidayaan ikan. Ruang lingkup keputusan tersebut diantaranya keamanan pangan pada usaha pembesaran ikan, penggunaan bahan budidaya dan keamanan pangan pada saat panen. Masing-masing ruang lingkup tersebut memiliki beberapa parameter dalam penerapannya.

Keputusan Menteri Kelautan dan Perikanan No. 2 Tahun 2007 menjelaskan bahwa agar keputusan tersebut dapat berjalan secara efisien dan efektif, menugaskan kepada Dinas Kelautan dan Perikanan untuk melakukan komunikasi dan sosialisasi kepada seluruh pemangku kepentingan tentang cara budidaya ikan yang baik (CBIB). Selain melakukan sosialisasi, Dinas Kelautan dan Perikanan perlu melakukan verifikasi dan sertifikasi terhadap semua usaha budidaya perikanan yang ada di wilayahnya. Upaya tersebut untuk memastikan bahwa semua usaha budidaya perikanan yang ada telah menempatkan kaidah cara budidaya ikan yang baik (CBIB).

\section{Metode}

Metode dasar yang digunakan dalam penelitian ini adalah penelitian deskriptif dengan instrumen penelitian berupa kuesioner. Penelitian deskriptif bertujuan untuk memberikan gambaran tentang suatu 
masyarakat, suatu kelompok orang tertentu atau gambaran tentang suatu gejala (Irawan, 2011). Teknik pengumpulan data dilakukan dengan wawancara dan observasi berstruktur untuk memperoleh gambaran lebih detail mengenai suatu gejala atau fenomena (Prasetyo \& Jannah, 2012). Lokasi penelitian ditentukan secara sampling purposive, yaitu dengan fokus di wilayah Dusun Sidorejo, Desa Banaran, Kecamatan Galur, Kabupaten Kulon Progo, serta Dusun Kuwaru dan Dusun Ngentak, Desa Poncosari, Kecamatan Srandakan, Kabupaten Bantul. Alasan pengambilan 3 wilayah tersebut dikarenakan sebagai sentra produksi udang vaname yang pertama dan paling lama beroperasi di pesisir Daerah Istimewa Yogyakarta. Responden ditentukan secara proportionate random sampling dari 3 wilayah yang telah ditentukan.

Teknik penghitungan seberapa besar penerapan cara budidaya ikan yang baik (CBIB) pada kegiatan pembesaran udang vaname di lokasi penelitian dilakukan dengan menggunakan skala nominal. Penghitungan dilakukan terhadap masing-masing ketentuan pada setiap parameter penerapan cara budidaya ikan yang baik. Penerapan CBIB terdiri dari 12 parameter, meliputi:

1. Pemilihan lokasi, berupa: lokasi terhidar dari daerah pemukiman, industri, lahan pertanian dan peternakan; kualitas air sumber sesuai peruntukan.

2. Penentuan tata letak dan desain konstruksi, mencakup: saluran pemasukan dan saluran pembuangan dibuat terpisah; tersedia petak tandon pada budidaya udang intensif dan semi intensif; tempat penyimpanan alat dan bahan budidaya tertutup serta terdapat sirkulasi udara; fasilitas toilet (MCK) terletak minimum $10 \mathrm{~m}$ dari petak pemeliharaan dan saluran.

3. Pemilihan wadah budidaya terbuat dari bahan yang tidak mudah korosif.

4. Pengamanan biologi (biosecurity) meliputi: bebas binatang peliharaan; tindakan isolasi terhadap ikan yang terserang penyakit.

5. Pemilihan benih ikan besertakan sertifikat atau surat keterangan bebas penyakit.

6. Penggunaan pakan ikan berupa: etiket menggunakan bahasa Indonesia; memiliki nomor pendaftaran yang dikeluarkan oleh otoritas kompeten; sesuai dengan ketentuan dan petunjuk pada etiket dan brosur.

7. Penggunaan obat ikan berupa: etiket menggunakan bahasa Indonesia; memiliki nomor pendaftaran yang dikeluarkan oleh otoritas kompeten; sesuai dengan ketentuan dan petunjuk pada etiket dan brosur.

8. Penggunaan probiotik berupa: etiket menggunakan bahasa Indonesia; memiliki nomor pendaftaran yang dikeluarkan oleh otoritas kompeten; sesuai dengan ketentuan dan petunjuk pada etiket dan brosur.

9. Penggunaan desinfektan berupa: etiket menggunakan bahasa Indonesia; memiliki nomor pendaftaran yang dikeluarkan oleh otoritas kompeten; sesuai dengan ketentuan dan petunjuk pada etiket dan brosur.

10.Penggunaan bahan kimia berupa: etiket menggunakan bahasa Indonesia; memiliki nomor pendaftaran yang dikeluarkan oleh otoritas kompeten; sesuai dengan ketentuan dan petunjuk pada etiket dan brosur.

11. Cara panen dilakukan dengan cepat dan cermat.

12.Peralatan panen terbuat dari bahan yang tidak mudah merusak fisik, tidak mudah korosif, dan mudah dibersihkan.

Teknik penghitungan penyuluhan, pencatatan, dan pengendalian cara budidaya ikan yang baik pada kegiatan pembesaran udang vaname di lokasi penelitian dilakukan dengan menggunakan skala nominal. Penghitungan dilakukan terhadap parameter berupa keberadaan penyuluhan, pencatatan, dan pengendalian oleh Dinas Kelautan dan Perikanan terhadap petambak di lokasi penelitian perihal cara budidaya ikan yang baik (CBIB).

\section{Hasil dan Pembahasan}

Penerapan Cara Budidaya Ikan yang Baik (CBIB)

Penerapan cara budidaya ikan yang baik (CBIB) pada kegiatan pembesaran udang di lokasi penelitian hanya terdiri dari 10 parameter dengan masingmasing ketentuan pada setiap parameter. Hal tersebut dikarenakan kegiatan pembesaran udang di lokasi penelitian belum menggunakan obat ikan (parameter nomor 7) dan bahan kimia (parameter nomor 10). Hasil pengamatan penerapan cara budidaya ikan yang baik (CBIB) oleh petambak di lokasi penelitian dapat dilihat pada tabel 1.

Penerapan cara budidaya ikan yang baik (CBIB) oleh petambak di lokasi penelitian rata-rata sebesar $62,24 \%$.

Penyuluhan, pencatatan, dan pengendalian CBIB Penerapan cara budidaya ikan yang baik (CBIB) seharusnya didukung dengan adanya penyuluhan (komunikasi dan sosialisasi), verifikasi (pencatatan) serta adanya pengendalian dari pihak Dinas Kelautan 
Tabel 1. Penerapan cara budidaya ikan yang baik (CBIB) di lokasi penelitian.

\begin{tabular}{|c|c|c|c|c|}
\hline \multirow{2}{*}{ Aspek penerapan CBIB } & \multicolumn{4}{|c|}{ Jumlah petambak (\%) di lokasi penelitian } \\
\hline & Sidorejo & Kuwaru & Ngentak & Rata-rata \\
\hline \multicolumn{5}{|l|}{ 1. Pemilihan lokasi } \\
\hline $\begin{array}{l}\text { a. Lokasi lahan budidaya terhindar dari daerah } \\
\text { pemukiman, industri, lahan pertanian dan } \\
\text { peternakan }\end{array}$ & 0100,00 & 0100,00 & 0100,00 & 0100,00 \\
\hline \multicolumn{5}{|l|}{ b. Kualitas air sumber sesuai peruntukan } \\
\hline 1) Salinitas & 0100,00 & 0100,00 & 0072,73 & 0090,91 \\
\hline 2) $\mathrm{pH}$ & 0062,50 & 0009,09 & 0009,09 & 0026,89 \\
\hline 3) Alkalinitas & 0100,00 & 0100,00 & 0100,00 & 0100,00 \\
\hline \multicolumn{5}{|l|}{ 2. Penentuaan tata letak dan desain konstruksi } \\
\hline a. Saluran pasok dan buang terpisah & 0100,00 & 0100,00 & 0100,00 & 0100,00 \\
\hline b. Tersedia petak tandon & 0012,50 & 0000,00 & 0000,00 & 0004,17 \\
\hline $\begin{array}{l}\text { c. Tempat penyimpanan alat dan bahan budidaya } \\
\text { yang tertutup dan memiliki sirkulasi udara }\end{array}$ & 0100,00 & 0100,00 & 0100,00 & 0100,00 \\
\hline d. Fasilitas MCK minimum 10 meter & 0037,50 & 0000,00 & 0000,00 & 0012,50 \\
\hline \multicolumn{5}{|l|}{ 3. Pemilihan wadah budidaya } \\
\hline a. Bahan yang tidak mudah korosif & 0100,00 & 0100,00 & 0100,00 & 0100,00 \\
\hline \multicolumn{5}{|l|}{ 4. Pengamanan biologi (biosecurity) } \\
\hline a. Bebas binatang peliharaan & 0050,00 & 0090,91 & 0072,73 & 0071,21 \\
\hline $\begin{array}{l}\text { b. Tindakan isolasi terhadap biota yang terserang } \\
\text { penyakit }\end{array}$ & 0000,00 & 0000,00 & 0000,00 & 0000,00 \\
\hline \multicolumn{5}{|l|}{ 5. Pemilihan benih } \\
\hline a. Bersertifikat bebas penyakit & 0100,00 & 0100,00 & 0100,00 & 0100,00 \\
\hline \multicolumn{5}{|l|}{ 6. Penggunaan pakan ikan (udang) } \\
\hline a. Etiket berbahasa Indonesia & 0100,00 & 0100,00 & 0100,00 & 0100,00 \\
\hline b. Memiliki nomor pendaftaran & 0100,00 & 0100,00 & 0100,00 & 0100,00 \\
\hline c. Sesuai ketentuan dan etiket & 0062,50 & 0045,45 & 0027,27 & 0045,08 \\
\hline \multicolumn{5}{|l|}{ 7. Penggunaan probiotik } \\
\hline a. Etiket berbahasa Indonesia & 0075,00 & 0072,73 & 0090,91 & 0079,55 \\
\hline b. Memiliki nomor pendaftaran & 0075,00 & 0072,73 & 0090,91 & 0079,55 \\
\hline c. Sesuai ketentuan dan etiket & 0000,00 & 0000,00 & 0000,00 & 0000,00 \\
\hline \multicolumn{5}{|l|}{ 8. Penggunaan desinfektan } \\
\hline a. Etiket berbahasa Indonesia & 0062,50 & 0054,55 & 0072,73 & 0063,26 \\
\hline b. Memiliki nomor pendaftaran & 0000,00 & 0000,00 & 0000,00 & 0000,00 \\
\hline c. Sesuai ketentuan dan etiket & 0000,00 & 0000,00 & 0000,00 & 0000,00 \\
\hline \multicolumn{5}{|l|}{ 9. Cara panen } \\
\hline a. Cepat dan cermat & 0075,00 & 0054,55 & 0045,45 & 0058,33 \\
\hline \multicolumn{5}{|l|}{ 10. Peralatan panen } \\
\hline $\begin{array}{l}\text { a. Bahan tidak merusak fisik, korosif, mudah } \\
\text { dibersihkan }\end{array}$ & 0100,00 & 0100,00 & 0100,00 & 0100,00 \\
\hline Jumlah & 1512,50 & 1400,01 & 1381,82 & 1431,44 \\
\hline Rata-rata & 0065,76 & 0060,87 & 0060,08 & 0062,24 \\
\hline
\end{tabular}


Tabel 2. Keberadaan penyuluhan (komunikasi dan sosialisasi) di lokasi penelitian.

\begin{tabular}{ccccc}
\hline Penyuluhan & \multicolumn{3}{c}{ Jumlah petambak (\%) di lokasi penelitian } \\
(komunikasi dan sosialisasi) & Sidorejo & Kuwaru & Ngentak & Rata-rata \\
\hline Ada & 037,50 & 000,00 & 000,00 & 012,50 \\
Belum ada & 062,50 & 100,00 & 100,00 & 087,50 \\
Jumlah & 100,00 & 100,00 & 100,00 & 100,00 \\
\hline
\end{tabular}

dan Perikanan mengenai cara budidaya ikan yang baik (CBIB). Hasil pengamatan adanya penyuluhan (komunikasi dan sosialisasi) dari Dinas Kelautan dan Perikanan perihal cara budidaya ikan yang baik (CBIB) terhadap petambak di lokasi penelitian dapat dilihat pada tabel 2 .

Penyuluhan (komunikasi dan sosialisasi) dari pihak Dinas Kelautan dan Perikanan terhadap petambak perihal cara budidaya ikan yang baik sebagian besar $87,50 \%$ belum ada, terdiri dari $62,50 \%$ pada wilayah Sidorejo; $100,00 \%$ di wilayah Kuwaru; $100,00 \%$ di wilayah Ngentak. Sebagian kecil petambak sudah memperoleh penyuluhan (komunikasi dan sosialisasi) dari pihak Dinas Kelautan dan Perikanan perihal cara budidaya ikan yang baik, terdiri dari $37,50 \%$ di wilayah Sidorejo; $0,00 \%$ di wilayah Kuwaru; $0,00 \%$ di wilayah Ngentak. Adanya verifikasi (pencatatan), serta adanya pengendalian dari pihak Dinas Kelautan dan Perikanan mengenai cara budidaya ikan yang baik secara umum belum diperoleh petambak di lokasi penelitian berlangsung. Berdasarkan penjelasan petambak di lokasi penelitian berlangsung, khususnya di wilayah Kuwaru dan Ngentak. Sejak awal hingga saat ini, selama berprofesi sebagai petambak, belum pernah merasa dianggap keberadaannya (profesi petambak) oleh otoritas kompeten. Petambak di wilayah Kuwaru dan Ngentak justru merasa keberadaannya tidak diinginkan, karena dianggap sebagai sumber pencemaran lingkungan. Pengetahuan petambak perihal teknis budidaya udang diperoleh justru bukan dari komunikasi dan sosialisasi oleh Dinas Kelautan dan Perikanan, melainkan dari karyawan dari pabrik pakan maupun probiotik udang.

Teknologi budidaya udang vaname

Teknologi budidaya udang vaname mencakup kedalaman air petak pembesaran, luas petak pembesaran, bentuk petak pembesaran, padat penebaran benih, lama pemeliharaan, sistem pemanenan, produksi total, rasio konversi pakan dan kelangsungan hidup udang vaname di lokasi penelitian berlangsung. Hasil pengamatan teknik budidaya udang vaname yang dikembangkan oleh para petambak di lokasi penelitian seperti tercantum pada tabel 3.

Kedalaman air petak pembesaran di lokasi penelitian rata-rata sebesar $1,22 \mathrm{~m}$, terdiri dari $1,21 \mathrm{~m}$ di wilayah Sidorejo; 1,25 m di wilayah Kuwaru; 1,20 m di wilayah Ngentak. Kedalaman air petak pembesaran berkisar antara 0,8-1,40 m menunjukan teknologi budidaya udang pada tingkat semi intensif (Badan Standardisasi Nasional, 2014 ${ }^{\mathrm{a}}$ ). Kedalaman air petak pembesaran lebih dari 1,40 m menunjukan teknologi budidaya udang pada tingkat intensif (Badan Standardisasi Nasional, 2014 ). Jika dilihat dari kedalaman air petak pembesaran yang ada, kedalaman air petak pembesaran di lokasi penelitian secara umum menunjukan penerapan teknologi budidaya udang pada tingkat semi intensif.

Tabel 3. Teknologi budidaya udang vaname di lokasi penelitian.

\begin{tabular}{lcccc}
\hline \multicolumn{1}{c}{ Parameter } & \multicolumn{3}{c}{ Lokasi penelitian } \\
& Sidorejo & Kuwaru & Ngentak & Rata-rata \\
\hline Kedalaman air petak pembesaran $(\mathrm{m})$ & 0001,21 & 0001,25 & 0001,20 & 0001,22 \\
Luas petak pembesaran $\left(\mathrm{m}^{2}\right)$ & 2210,88 & 679,73 & 1007,27 & 1299,29 \\
Bentuk petak pembesaran & Persegi & Persegi & Persegi & Persegi \\
& & panjang & panjang & panjang \\
Padat penebaran benih (ekor $\left./ \mathrm{m}^{2}\right)$ & 204,00 & 110,00 & 166,00 & 160,00 \\
Lama pemeliharaan (hari) & 091,00 & 072,00 & 074,00 & 079,00 \\
Sistem pemanenan & Parsial & Total & Total & Total \\
Produksi total $\left(\mathrm{kg} / \mathrm{m}^{2}\right)$ & 002,30 & 001,13 & 001,44 & 001,62 \\
Rasio konversi pakan & 001,27 & 001,13 & 001,44 & 001,28 \\
Kelangsungan hidup udang $(\%)$ & 079,53 & 068,89 & 067,83 & 072,08 \\
\hline
\end{tabular}


Luas petak pembesaran di lokasi penelitian rata-rata seluas $1.299,29 \mathrm{~m}^{2}$, terdiri dari $2.210,88 \mathrm{~m}^{2}$ di wilayah Sidorejo; 679,73 $\mathrm{m}^{2}$ di wilayah Kuwaru; 1.007,27 m² di wilayah Ngentak. Luas wadah budidaya berkisar antara 1000 - $5000 \mathrm{~m}^{2}$ menunjukan teknologi budidaya udang pada tingkat semi intensif (Badan Standardisasi Nasional, 2014 ${ }^{\mathrm{a}}$ ) dan tingkat intensif (Badan Standardisasi Nasional, 2014 ${ }^{\mathrm{b}}$ ). Jika dilihat dari luas petak pembesaran yang ada, maka luas petak pembesaran di lokasi penelitian secara umum menunjukan penerapan teknologi budidaya udang pada tingkat semi intensif maupun intensif.

Bentuk petak pembesaran di lokasi penelitian ratarata berbentuk persegi panjang, terdiri dari persegi di wilayah Sidorejo; persegi panjang di wilayah Kuwaru; persegi panjang di wilayah Ngentak. Bentuk petak pembesaran persegi dan persegi panjang menunjukan teknologi budidaya udang pada tingkat semi intensif (Badan Standardisasi Nasional, 2014 ${ }^{\mathrm{a}}$ ) dan intensif (Badan Standardisasi Nasional, 2014 ${ }^{\mathrm{b}}$ ). Jika dilihat dari bentuk petak pembesaran yang ada, petak pembesaran di lokasi penelitian secara umum menunjukan penerapan teknologi budidaya udang pada tingkat semi intensif maupun intensif.

Pada penebaran benih udang di lokasi penelitian ratarata sebesar 160 ekor $/ \mathrm{m}^{2}$, terdiri dari 204 ekor $/ \mathrm{m}^{2}$ di wilayah Sidorejo; 110 ekor/m² di wilayah Kuwaru; 166 ekor $/ \mathrm{m}^{2}$ di wilayah Ngentak. Padat penebaran benih udang berkisar antara 50 - 79 ekor/m² menunjukan teknologi budidaya udang pada tingkat semi intensif (Badan Standardisasi Nasional, 2014 ${ }^{\mathrm{a}}$ ). Padat penebaran benih udang berkisar antara 80 - 120 ekor $/ \mathrm{m}^{2}$ menunjukan teknologi budidaya udang pada tingkat intensif (Badan Standardisasi Nasional, $2014^{\text {b }}$ ). Jika dilihat dari padat penebaran benih udang yang ada, padat penebaran benih udang di lokasi penelitian secara umum diatas indikator penerapan teknologi budidaya udang pada tingkat semi intensif maupun intensif.

Lama pemeliharaan udang di lokasi penelitian ratarata selama 79 hari, terdiri dari 91 hari di wilayah Sidorejo; 72 hari di wilayah Kuwaru; 74 hari di wilayah Ngentak. Lama pemeliharaan udang udang maksimal selama 60 hari menunjukan teknologi budidaya udang pada tingkat semi intensif (Badan Standardisasi Nasional, 2014 ${ }^{\mathrm{a}}$ ). Lama pemeliharaan udang maksimal selama 90 hari menunjukan teknologi budidaya udang pada tingkat intensif (Badan Standardisasi Nasional, 2014 ${ }^{\mathrm{b}}$ ). Jika dilihat dari padat lama pemeliharaan udang yang ada, durasi pemeliharaan udang di lokasi penelitian secara umum menunjukan penerapan teknologi budidaya udang pada tingkat intensif.

Sistem pemanenan di lokasi penelitian rata-rata secara total, terdiri dari parsial di wilayah Sidorejo; total di wilayah Kuwaru; total di wilayah Ngentak. Panen udang dapat dilakukan secara parsial ataupun total. Panen parsial dilakukan dengan memanen sebanyak 20 - 30\% dari total jumlah udang. Panen parsial biasanya dilakukan menggunakan jala kantong sehingga udang yang tertangkap tidak mudah terlepas. Panen total dilakukan dengan menggunakan jaring kantong yang dipasang pada pintu air kemudian dilanjutkan jaring tarik (jaring arad). Udang yang masih tersisa dapat diambil menggunakan tangan (Idham et al., 2014).

Produksi total udang vaname meliputi hasil panen keseluruhan atau produksi total udang dalam satuan $\mathrm{kg} / \mathrm{m}^{2}$. Produksi total di lokasi penelitian ratarata $1,62 \mathrm{~kg} / \mathrm{m}^{2}$, terdiri dari $2,30 \mathrm{~kg} / \mathrm{m}^{2}$ di wilayah Sidorejo; 1,13 kg/m² di wilayah Kuwaru; $1,44 \mathrm{~kg} / \mathrm{m}^{2}$ di wilayah Ngentak. Produksi total udang berkisar antara 0,4 - 0,8 kg/m² merupakan cerminan dari penerapan teknologi budidaya udang pada tingkat semi intensif (Badan Standardisasi Nasional, 2014 ${ }^{\mathrm{a}}$ ). Produksi total udang lebih dari $0,9 \mathrm{~kg} / \mathrm{m}^{2}$ merupakan cerminan dari penerapan teknologi budidaya udang pada tingkat intensif (Badan Standardisasi Nasional, $2014^{\text {b }}$. . Jika dilihat dari produksi total udang yang ada, produksi total udang di lokasi penelitian secara umum mencerminkan penerapan teknologi budidaya udang pada tingkat intensif.

Konversi pakan udang vaname di lokasi penelitian meliputi rasio konversi pakan. Rasio konversi pakan adalah jumlah total berat pakan buatan dibandingkan dengan jumlah berat total udang hasil panen (Idham et al., 2014). Konversi pakan udang petambak di lokasi penelitian rata-rata 1,28 , terdiri dari 1,27 di wilayah Sidorejo; 1,13 di wilayah Kuwaru; 1,44 di wilayah Ngentak. Konversi pakan udang maksimal 1,5 merupakan cerminan dari penerapan teknologi budidaya udang pada tingkat semi intensif (Badan Standardisasi Nasional, 2014 ${ }^{\mathrm{a}}$ ) dan intensif (Badan Standardisasi Nasional, 2014 ${ }^{\mathrm{b}}$ ). Jika dilihat dari konversi pakan udang yang ada, konversi pakan udang di lokasi penelitian secara umum mencerminkan penerapan teknologi budidaya udang pada tingkat semi intensif maupun intensif.

Kelangsungan hidup udang vaname di lokasi penelitian meliputi kelangsungan hidup udang dalam satuan $\%$. Kelangsungan hidup adalah persentase jumlah udang yang hidup pada saat panen dibandingkan dengan jumlah udang yang ditebar (Badan Standardisasi Nasional, 2014 ${ }^{\text {b }}$. Kelangsungan hidup udang di lokasi penelitian rata-rata $72,08 \%$, terdiri dari $79,53 \%$ di wilayah Sidorejo; 68,89\% di wilayah Kuwaru; $67,83 \%$ di wilayah Ngentak. Kelangsungan hidup udang minimal $80 \%$ merupakan cerminan dari 
penerapan teknologi budidaya udang pada tingkat semi intensif (Badan Standardisasi Nasional, 2014 ${ }^{\mathrm{a}}$ ) dan intensif (Badan Standardisasi Nasional, 2014 ). Jika dilihat dari kelangsungan hidup udang yang ada, kelangsungan hidup udang di lokasi penelitian secara umum dibawah cerminan kelangsungan hidup udang pada tingkat teknologi semi intensif maupun intensif.

\section{Kesimpulan dan Saran}

Kesimpulan

Penerapan cara budidaya ikan yang baik (CBIB) oleh petambak pada kegiatan pembesaran udang vaname (L. vannamei) di pesisir Daerah Istimewa Yogyakarta rata-rata sebesar 62,24\%. Faktor yang mempengaruhi penerapan cara budidaya ikan yang baik adalah belum intensifnya sosialisasi tentang materi CBIB oleh pemerintah. Pengetahuan perihal cara budidaya ikan yang baik (CBIB) yang diperoleh petambak justru berasal dari karyawan pabrik pakan maupun probiotik udang. Teknologi budidaya udang yang diterapkan oleh petambak udang vaname $(L$. vannamei) di pesisir Daerah Istimewa Yogyakarta adalah semi intensif.

\section{Saran}

Perlu dilakukannya penyuluhan (komunikasi dan sosialisasi), verifikasi (pencatatan) dan pengendalian berupa sertifikasi dari pihak otoritas kompeten mengenai cara budidaya ikan yang baik (CBIB) atau teknis pembesaran udang terhadap petambak. Adanya penyuluhan (komunikasi dan sosialisasi), verifikasi (pencatatan) serta pengendalian dari pihak otoritas kompeten diharapkan mampu meningkatkan rata-rata penerapan cara budidaya ikan yang baik pada kegiatan pembesaran udang vaname ( $L$. vannamei) di pesisir Daerah Istimewa Yogyakarta.

\section{Ucapan Terima Kasih}

Ucapan terima kasih diucapkan kepada Susilo Budi Priyono, S.Pi., M.Si atas kontribusi berupa arahan dan bimbingan sehingga artikel ilmiah ini dapat ditulis.

\section{Daftar Pustaka}

Badan Standardisasi Nasional. 2014a . Produksi Udang Vaname (Litopenaeus vannamei Boone, 1931) Semi Intensif di Tambak Lining. Badan Standardisasi Nasional (BSN), Jakarta.

Badan Standardisasi Nasional. 2014b. Produksi Udang Vaname (Litopenaeus vannamei Boone, 1931) Intensif di Tambak Lining. Badan Standardisasi Nasional (BSN), Jakarta.

Direktorat Jenderal Perikanan Budidaya. 2013. Budidaya Udang Vaname di Tambak. Direktorat Jenderal Perikanan Budidaya. BBAP Situbondo, Situbondo.

Idham, M., S. Wahju, M. Yusuf., A. Nur \& C. Yusuf. 2014. Budidaya Udang Vannamei. WWFIndonesia, Jakarta.

Irawan, S. 2011. Metode Penelitiaan Sosial. Edisi 8. PT. Remaja Rosdakarya, Bandung.

Keputusan Menteri Perikanan dan Kelautan. 2007. Cara Budidaya Ikan yang Baik. Keputusan Menteri Perikanan dan Kelautan nomor 2 tahun 2007, Jakarta.

Prasetyo, B. \& L. M. Jannah. 2012. Metode Penelitian Kualitatif. PT Raja Grafindo Persada, Jakarta. 